\author{
Military Technical College
} Kobry Elkobbah, Cairo, Egypt.

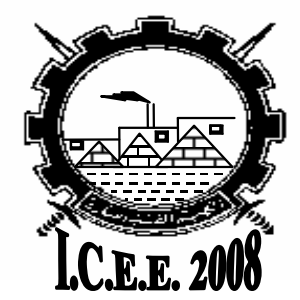

$4^{\text {th }}$ International Conference

On

Chemical \& Environmental

Engineering

27-29 May 2008

\title{
REMOVAL OF SOME POLLUTANTS BY POLY INORGANIC COAGULANTS BASED ON SILICA DERIVED FROM RICE HUSK ASH
}

\author{
S. A. Abo-El-Enein ${ }^{1}$, M. A. Eissa ${ }^{2}$, A. A. Diafullah ${ }^{3}$ \\ M. A. Rizk ${ }^{4}$, and F. M. Mohamed ${ }^{5}$
}

\begin{abstract}
:
Coagulation is one of the most important steps during the conventional water treatment train. Salts and prehydrolysed salts of aluminum and iron were used as coagulants in water and waste water treatment; These effective materials play a vital role in the removal of a board range of impurities from water including colloidal particles, dissolved organic substances and some heavy metals.

Because of superior efficiency and relatively low cost of these materials compared with traditional coagulant alum, aluminum salts and iron salted of the prehydrolysed iron and aluminum salts with active silica were favorable in addition to the following features: very fast hydrolysis, promote rapid settling rates, extremely efficient in cold water, give low soluble residual aluminum, consume less alkalinity, very little effect on $\mathrm{pH}$, increase stability of coagulant and denser compacted sludge.

The objective of this study is to prepare four new types of poly inorganic co-agulants (PIC); these are poly aluminum chloride silicate ( $\mathrm{PACISi}$ ), poly hydroxy aluminum sulphate silicate ( PHASSi ), poly ferric chloride silicate ( PFeCISi ), and poly ferric aluminum chloride silicate ( PFeAICISi ) based on silica. The characterization of the materials obtained was carried out by means of by FTIR, NFTIR, XRD, and SEM., in order to select the optimum condition suitable for removal of some pollutants. Under this study the maximum removal of some ground water pollutants as turbidity , colour, $\mathrm{Fe}, \mathrm{Mn}, \mathrm{Pb}, \mathrm{As}, \mathrm{NO}_{3}^{-1}$ and $\mathrm{F}^{-1}$ are about $70 \%, 75 \% 97.5 \%, 96 \%, 97 \%, 97 \%$, $97 \%$, and $99 \%$ respectively ; the maximum removal of $\mathrm{Pb}$ in industrial waste water reach to $99 \%$; the maximum removal of $\mathrm{BOD}, \mathrm{COD}$ and TSS in sewage waste water are $92 \%, 90 \%, 93 \%$, respectively .
\end{abstract}

KEY WORDS : Inorganic coagulants. silica based coagulants and Waste water Treatment.

\footnotetext{
${ }^{1}$ faculty of science, Ain shams university, Egypt.

${ }^{2}$ Kaha Company for Chemical Industries, National Authority for Military Production. Egypt

${ }^{3}$ Atomic Energy Authority, Egypt

${ }^{4}$ Atomic Energy Authority, Egypt

${ }^{5}$ Kaha Company for Chemical Industries, National Authority for Military Production. Egypt
} 


\section{INTRODUCTION}

Aluminum and ferric salts are widely used as coagulants in water and wastewater treatment. These materials have been applied routinely since early in the $20^{\text {th }}$ century and play a vital role in the removal of many impurities from polluted waters. They are effective in removing a broad range of impurities from water, including colloidal particles, dissolved organic substances and dissolved constituents from water beside arsenic, notably turbidity, iron, manganese, phosphate, fluoride. Their mode of action is broadly understood Charged colloids by cationic hydrolysis products and incorporation of impurities in an amorphous precipitate of metal hydroxide. The relative importance of these two mechanisms depends on many factors, especially $\mathrm{pH}$ and coagulant dosage[1].

All ions in water are hydrated to some extent. In the case of $\mathrm{Al}^{3+}$ and $\mathrm{Fe}^{3+}$, there is a primary hydration shell with six octahedrally coordinated water molecules, e.g., $\mathrm{Al}\left(\mathrm{H}_{2} \mathrm{O}\right)_{6}{ }^{3+}$ and $\mathrm{Fe}\left(\mathrm{H}_{2} \mathrm{O}\right)_{6}{ }^{3+}$. Hydrolysis of such ions is often represented as a sequential replacement of the water molecules by hydroxyl ions, and can also be thought of as a progressive deprotonation of water molecules in the primary hydration shell, the hydrolysis of aluminum salt could produce a series of products ranging from monomers, oligomers to polymeric hydroxyl complexes. Most of them, such as, $\quad \mathrm{Al}(\mathrm{OH})_{3(\mathrm{am})} \mathrm{Al}(\mathrm{OH})_{2}{ }^{+}, \mathrm{Al}(\mathrm{OH})^{2+}, \mathrm{Al}^{3+}, \mathrm{Al}_{2}(\mathrm{OH})_{2}{ }^{4+}, \mathrm{Al}_{3}(\mathrm{OH})_{4}{ }^{5+}$ and $\mathrm{Al}_{13} \mathrm{O}_{4}(\mathrm{OH})_{24}{ }^{7+}$ (tridecameric polymer or ' $\mathrm{Al} \mathrm{l}_{13}$ '), [2] the simplest representation, for $\mathrm{Al}^{3+}$, and $\mathrm{Fe}^{3+}$ omitting the hydration shell for convenience, is:

$\mathrm{Al}^{3+} \rightarrow \mathrm{Al}(\mathrm{OH})^{2+} \rightarrow \mathrm{Al}(\mathrm{OH})_{2}^{+} \rightarrow \mathrm{Al}(\mathrm{OH})_{3} \rightarrow \mathrm{Al}(\mathrm{OH})_{4}{ }^{1-}$

$\mathrm{Fe}^{3+} \rightarrow \mathrm{Fe}(\mathrm{OH})^{2+} \rightarrow \mathrm{Fe}(\mathrm{OH})_{2}{ }^{+} \rightarrow \mathrm{Fe}(\mathrm{OH})_{3} \rightarrow \mathrm{Fe}(\mathrm{OH})_{4}{ }^{1-}$

Since each step involves the loss of a proton, increasing $\mathrm{pH}$ causes the equilibrium to be shifted to the right. Aluminum hydroxide has low solubility in water, and precipitation occurs at intermediate $\mathrm{pH}$ values. Further increase of $\mathrm{pH}$ causes the soluble aluminate ion to be formed. A similar sequence can be written in the case of $\mathrm{Fe}^{3+}$. In this case, the hydroxide is much less soluble than aluminum hydroxide[2].

Coagulants are one of the key factors in the coagulation process. Alum is the most frequently applied traditional coagulant in the world. Recently, based on conventional iron and aluminum salts, inorganic polymer flocculants (IPFs) have been developed rapidly and become applied widely, especially in China, Japan, Russia, and west Europe [3-6]. Many kinds of IPFs have been developed including aluminum-based, iron-based, inorganic-inorganic composite flocculants, inorganic-organic composite flocculants, and multifunctional composite IPFs [3-9]. A number of experimental methods and approaches have been applied. Apart from normal chemical analysis, the analytical methods applied were potential titration, small angle X-ray diffraction, infrared spectroscopy, nuclear magnetic resonance spectroscopy, laser light scattering, small angle X-ray scattering, various electron microscopy, and atomic force microscopy. The timed spectrophotometer method involving reaction of 8hydroxyquinoline or ferron (8-hydroxy-7-iodo-5-quinoline-sulfonic acid) has also been widely applied to quantify the different species present[10-18].

In water treatment, the pre-polymerized aluminium salts offer a number of potential benefits in comparison to the precursor Al salts. These benefits were noted to varying degrees depending on the characteristic properties of the raw water; improved performances in the overall coagulation-flocculation- sedimentation processes' improved performances in conditions which often limit the rate and extent 
of hydrolysis and coagulation, e.g. low $\mathrm{pH}$, low alkalinity, presence of organic contaminants ' and low temperatures, reduced levels of residual soluble Al species, reduced requirements for organic polymer flocculants and lower pre- or post flocculation $\mathrm{pH}$ adjustments needed $[19,20]$.

Aluminum salts and activated silica, a sort of polysilicate (PSi), can be combined under some conditions to prepare PASiC coagulant. They may be prepolymerized by hydroxylation individually or mixed initially in their original form and then hydrolyzed together[21-22], some studies demonstrated that adding Al or other salts can delay the gelation time of activated silica Also, there are several reports indicating that aluminum-silicate polymer composites are highly effective for removal of turbidity and humics and for treatment of cold water [23-24].

The IPFs, such as poly aluminium chloride (PACl) and poly iron chloride (PICl), are a category of partially neutralized metal salts with significant polymeric fraction present in some circumstances. Preformed polymerized species have the advantages of being more effective under a variety of water quality conditions, especially at lower temperatures and a broader $\mathrm{pH}$ ranges relative to alum [25-27].

Previous studies paid most attention to the effect of alkalinity on the coagulation behaviors of traditional coagulants, and little study has been focused on the effect of alkalinity on coagulation with PACls, It has been observed that demand for alum increases linearly with increased alkalinity and turbidity is hard to remove when alkalinity drops below $30 \mathrm{mg} / \mathrm{L}$ as $\mathrm{CaCO}_{3}$,Alkalinity also plays a key role in the enhanced coagulation to remove NOM, since it tends to keep coagulation pH higher and reduce NOM removal. PACls could be less affected by alkalinity than alum, particularly those PACls with higher basicity [28-29].

The general mechanisms of coagulation have been summarized in Duan and Gregory's review in detail [30]. Colloidal destabilization can be achieved by adding alum, and the corresponding mechanism involved is called charge neutralization. Due to the extremely low solubility of aluminum, with increase of alum dosage, rapid and excessive aluminum hydroxide precipitation can form and fine particles in water can be enmeshed in the hydroxide precipitate, and thus efficient turbidity removal is achieved. This process is the so-called sweep flocculation mechanism since particles are swept out of water by an amorphous hydroxide precipitate. Chowdhury and Amy [31]. claimed that precipitation is the main mechanism in the coagulation of alumina colloids with alum. According to the 'sweep flocculation' model, the incorporation of colloids into precipitate follows two pathways: one is the heterogeneous nucleation involving charge neutralization and subsequent growth of precipitate at low $\mathrm{pH}$ values, and the other is homogeneous nucleation involving precipitation and subsequent particle aggregation at high $\mathrm{pH}$ values. In this study, the former pathway is regarded as charge neutralization and the latter one as sweep flocculation. With respect to the coagulation/flocculation mechanisms of PACls, most current studies focused on the mode of charge neutralization [32-33]. tried to explain the coagulation mechanisms of different kinds of coagulants by a combined model of precipitation charge neutralization (PCN). Recently, 'electrostatic patch coagulation' (EPC) was proposed by Wang et al. [34].

The objective of this study is to prepare four new types of poly inorganic co-agulants (PIC); these are poly aluminum chloride silicate (PACISi)., poly hydroxy aluminum sulphate silicate (PHASSi.) poly ferric chloride silicate (PFeCISi),poly ferric aluminum chloride silicate (PFeAICISi ) based on silica. The characterization of the materials 
obtained was carried out by means of by FTIR, NFTIR, XRD, and SEM. in order to select the optimum condition suitable for removal of some pollutants.

\section{Materials and Experimental procedure}

\subsection{Materials}

All reagents(aluminum chloride, ferric chloride, aluminum sulphate, sodium carbonate ) used are analytically pure chemicals except sodium silicate which is a commercial grade product prepared from RHA and pure sodium hydroxide .Deionized water was used to make all solutions.

\subsection{Experimental}

The experimental part is divided into two main sections:

(i) The first section is subdivided into two parts:

the first part concerns with preparation of poly silicic acid solution ( PSi) from sodium silicate based on RHA was chosen as a precursor for the preparation, by dilution of sodium silicate containing $15 \% \quad \mathrm{SiO}_{2}$ with distilled water to a concentration of $0.25 \mathrm{M} \mathrm{SiO}_{2}$. The diluted solution was reacted with $0.25 \mathrm{HCl}$ under magnetic stirring, the $\mathrm{pH}$ of final solution about 2 and $\mathrm{SiO}_{2}$ concentration reaches $0.125 \mathrm{M}$, the second part concerns with the preparation and characterization of a new four poly inorganic coagulants namely poly aluminum chloride silicate (PACISi), poly hydroxy aluminum sulphate silicate (PHASSi.) poly ferric chloride silicate (PFeCISi), poly ferric aluminum chloride silicate (PFeAICISi ). The preparation was done by the slight neutralization of inorganic coagulant $\left(0.25 \mathrm{M} \mathrm{AlCl}_{3}, 0.125 \mathrm{M} \mathrm{Al}_{2}\left(\mathrm{SO}_{4}\right)_{3}, 0.25 \mathrm{M} \mathrm{FeCl}_{3}\right.$, and $\left(0.25 \mathrm{M} \mathrm{ALCl} \mathrm{Al}_{3}\right.$ or $\mathrm{FeCl}_{3}$ ) with sodium carbonate $0.25 \mathrm{M}$ at $60{ }^{\circ} \mathrm{C}$ with rapid mixing to obtain $[\mathrm{Y}=2$, $\left.B=67, r_{1}=0.1\right],\left[\gamma=1.5, B=50 \% r_{1}=0.1\right] .\left[\gamma=2, B=67 \%, r_{2}=0.2\right]$, and $[\gamma=2, B=67$ $\left.\%,-r_{1}=0.1 r_{2}=0.2\right]$ respectively where $y$ is the molar ratio of $[\mathrm{OH}] /[\mathrm{AL}], \quad B$ represents the basicity, the $r_{1}$ is the molar ratio of aluminum to silicon and $r_{2}$ is the molar ratio of iron to silicon .

(ii) The second section is subdivided into three main parts:

the first part concerns with the removal of some pollutants from ground water such as iron ,manganese, arsenic, lead, fluoride, and nitrate ions in addition to turbidity and colour using representative sample obtained from a certain well. The second part concerns with the removal lead from industrial waste water. The third part concerns with removal of BOD, COD and TSS from sewage waste water to obtain the water quality for re-use in agricultural drip irrigation system. Whereas, the treatment is depended on precipitation ,coagulation and adsorption technique using poly inorganic coagulants(PIC), Each sample was mixed with $5-10 \mathrm{ppm}$ of PIC and agitated for 1minute rapid mix (300rpm), 5 minutes slow mix (30rpm), 20 minutes (standing time The concentration was measured in the filtrate using AAS and normal analytical methods according to ASTM. 


\section{Results and discussions}

\subsection{The first section:}

The data listed in Table (1) represent the chemical composition of four samples of poly inorganic coagulants, namely, poly aluminium chloride silicate (PACISi), poly hydroxy aluminium sulphate silicate (PHASSi.) poly ferric chloride silicate (PFeCISi),poly ferric aluminium chloride silicate (PFeAICISi )Fig.1a shows the FTIR spectrum of poly aluminium hydroxy sulphate silicate (PAHSSi), the spectrum displayed the characteristic bands of $\mathrm{OH}$ - stretch, $\mathrm{H}_{2} \mathrm{O}$ bend, $\mathrm{AL}-\mathrm{OH}_{2}$ bend, Si-O stretching $\mathrm{SiO}(\mathrm{OH})_{3}, \mathrm{Al}-\mathrm{O}$ symmetric stretch $\mathrm{SO}_{4}$, and or Al-O-Si, symmetrical and anti-symmetrical $\mathrm{ALO}_{4}$ at 3372, $1671,1135 \mathrm{~cm}^{-1}, 606$, and $505 \mathrm{~cm}^{-1}$, respectively [3536]. Fig.1b) shows the FTIR spectrum of poly aluminium chloride silicate (PACSi), the spectrum displayed the characteristic bands for $\mathrm{Si}-\mathrm{OH}$ stretching, $\mathrm{OH}$ - stretch, $\mathrm{H}_{2} \mathrm{O}$ bend, $\mathrm{AL}-\mathrm{OH}_{2}$ bend, Si-O stretching $\mathrm{SiO}(\mathrm{OH})_{3}, \mathrm{Al}-\mathrm{O}$ symmetric stretch ,and or Al-O-Si symmetrical and anti-symmetrical $\mathrm{ALO}_{4}^{-1}$ at $3735,3435,1636,1086,983$ and, $(598,422) \mathrm{cm}^{-1}$, respectively [35-36]. Fig. 1c shows the FTIR spectrum of poly ferric chloride silicate ( $\mathrm{PFeCISi}$ ), the spectrum displayed the characteristic bands of Si-OH stretching, $\mathrm{OH}$ - stretch, $\mathrm{H}_{2} \mathrm{O}$ bend $\mathrm{Fe}^{-} \mathrm{OH}_{2}$ bend, Si-O stretching $\mathrm{SiO}(\mathrm{OH})_{3}$, $\mathrm{Fe}-\mathrm{O}$ symmetric stretch, Fe-O-Si or symmetrical and anti-symmetrical $\mathrm{FeO}_{4}{ }^{-1}$ at 3876 , $3383,1619,1082,958,689$, and, $(465,417) \mathrm{cm}^{-1}$ respectively [35-36] Fig.1d) shows the FTIR spectrum of poly aluminum ferric chloride silicate PAIFeCLSi, the spectrum displayed the characteristic bands for $\mathrm{OH}$ - stretch, $\mathrm{H}_{2} \mathrm{O}-\mathrm{OH}$ stretch, $\mathrm{H}_{2} \mathrm{O}$ bend $\mathrm{AL}$ $\mathrm{OH}_{2}$ bend, Si-O stretching $\mathrm{SiO}(\mathrm{OH})_{3}, \mathrm{Al}-\mathrm{O}$ symmetric , and or Al-O-Si and antisymmetrical $\mathrm{ALO}_{4}{ }^{-1}\left(\mathrm{FeO}_{4}{ }^{-1}\right)$ at $3413,1629,1121,898,702$, and $480 \mathrm{~cm}^{-}$ ${ }^{1}$ respectively,[35-36].

Fig.2a shows NFTIR spectrum of Poly aluminium chloride silicate (PACSi), the spectrum displayed the characteristic bands of overtone $\mathrm{OH}$ - stretch $\mathrm{Si}-\mathrm{OH}$, overtone $\mathrm{OH}$ - stretch(1)AIOH, combination of $(\mathrm{OH}$-stretching $(1+2) \mathrm{AlOH}+$ crystal water ,overtone $\mathrm{OH}$-stretching $\mathrm{AlOH}$ vicinity $\mathrm{AlOH}_{4}, \mathrm{H}_{2} \mathrm{O}$ combination (bend $1+$ stretch 1 ) $\mathrm{Al}_{13}$ ), $\mathrm{H}_{2} \mathrm{O}$ combination (bend $2+$ stretch 1 ) crystal $\mathrm{H}_{2} \mathrm{O}+\mathrm{Al}_{13}$ ) and combination $\mathrm{AIOH}$ (stretch $1+$ bend 3 or 4) at 7326 ( 7040,6984 and 6914) ,(6823-6787), 5436 , 5341, 5181, and $4463 \mathrm{~cm}^{-1}$ respectively[36-37]. Fig.2b shows NFTIR spectrum of Poly aluminium hydroxy sulphate silicate (PAHSSi), the spectrum displayed the characteristic bands of overtone $\mathrm{OH}$ - stretch $\mathrm{Si}-\mathrm{OH}$, overtone $\mathrm{OH}$ - stretch , (1) $\mathrm{AlOH}$ ,combination of $\left(\mathrm{OH}\right.$-stretching(1+2) $\mathrm{AlOH}+$ crystal water overtone $\mathrm{OH}$-stretch $(2) \mathrm{H}_{2} \mathrm{O}$, overtone $\mathrm{OH}$-stretching $\mathrm{AlOH}$ vicinity $\mathrm{AlOH}_{4}, \mathrm{H}_{2} \mathrm{O}$ combination (bend $1+$ stretch 1 ) $\mathrm{Al}_{13}$ ) , $\mathrm{H}_{2} \mathrm{O}$ combination (bend $2+$ stretch 1 ) crystal $\mathrm{H}_{2} \mathrm{O}+\mathrm{Al}_{13}$ ) at 7336, , 7020,6982 and 6914$),(6871,5436 \mathrm{c}, 5341)$ and $5177 \mathrm{~cm}^{-1}$ respectively[36-37]. Fig.2c shows NFTIR spectrum of poly ferric chloride (PFeCISi), the spectrum displayed the characteristic bands for overtone $\mathrm{OH}$ - stretch $\mathrm{Si}-\mathrm{OH}$,overtone $\mathrm{OH}$ - stretch, (1) $\mathrm{FeOH}$, combination of $(\mathrm{OH}$-stretching(1+2) $\mathrm{FeOH}+$ crystal water, overtone $\mathrm{OH}$-stretch (2) crystal $\mathrm{H}_{2} \mathrm{O}$, (overtone $\mathrm{FeOH}(3 / 4)$ bend, overtone $\mathrm{OH}$-stretch $\mathrm{FeOH}$ vicinity $\mathrm{FeOH}_{4}$ ), $\mathrm{H}_{2} \mathrm{O}$ combination ( bend $2+$ stretch 1 ) crystal $\mathrm{H}_{2} \mathrm{O}+\mathrm{Al}_{13}$ )and combination $\mathrm{H} 2 \mathrm{O}$ ( bend $2+$ stretch 2) crystal $\mathrm{H}_{2} \mathrm{O}$ combination $\mathrm{FeOH}$ at 7378 , (6898), (6813 and 6732 ) and $6600-6060,5880$ and $5513,5138,4565 \mathrm{~cm}^{-1}$ respectively [36-37] fig.2d shows NFTIR spectrum of Poly aluminium ferric chloride silicate (PAIFeCSi), the spectrum displayed the characteristic bands of overtone $\mathrm{OH}$ - stretch $\mathrm{Si}-\mathrm{OH}$, overtone $\mathrm{OH}$ - stretch, (1) $\mathrm{FeOH} / \mathrm{AlOH}$ combination of $(\mathrm{OH}$-stretching(1+2) $\mathrm{FeOH}$ or $\mathrm{AlOH}+$ 
crystal water, $\mathrm{H}_{2} \mathrm{O}$ combination (bend $1+$ stretch 1 ) $\mathrm{Al}_{13}$ ) combination (bend $2+$ stretch 1 ) crystal $\left.\mathrm{H}_{2} \mathrm{O}+\mathrm{Al}_{13}\right)$ or at $(7368,7326) 7040,(6802-6743),(6446-6366)$, and $5199 \mathrm{~cm}^{-1}$ respectively [36-37]:FTIR and NFTIR were summarized in table 2 \&3.

Fig.(3) shows SEM micrograph of PACSi $-\mathrm{C}_{2} \mathrm{O}_{4}$ which indicates the hexagonal crystalline form; Fig.(4) shows the SEM micrograph of $\mathrm{PACSi}^{-S \mathrm{~S}_{4}}$ which identifies by the fiber shaped and monoclinic rectangle crystalline form, Fig.(5) shows SEM micrograph of PAHSSi which indicates the mono clinic rectangle crystalline form; fig.(6) shows SEM the scan electron microscope of PFeCISi which identifies by the spherical form with aggregates and Fig.(7) shows SEM micrograph of PFeAICISi which identifies by the spherical form with aggregates.

Fig. (8) shows the X-ray diffractogram of poly aluminum chloride silicate (PACSi), which indicates the silica abroad peak appeared around $2 \theta$ equal to $22^{\circ}$ [38], high intensity and sharp peaks in the range of $2 \theta$ from 5 to $25^{\circ[38]}$, which indicates that there is $\mathrm{Al}_{13}$ species in $\mathrm{PAC}-\mathrm{Al}_{13}$ [38]; Fig. (9) shows the X-ray diffractogram of poly aluminum hydroxy sulphate silicate (PAHSSi), which indicates the amorphous silica appeared abroad peak around $2 \theta$ equal to $22^{\circ}$, peaks in the range of $2 \theta$ from 5 to $25^{\circ}$ [38], which indicates that there is $\mathrm{Al}_{13}$ species in $\mathrm{PAC}_{13} \mathrm{Al}_{13}$ and amorphous sulphate ${ }^{[38]}$, Fig. (10) shows the X-ray diffractogram of poly ferric chloride silicate (PFeCSi), which indicates the amorphous silica board peak appeared around $2 \theta$ equal to $22^{\circ}\left[38\right.$ ] and the peak in the range of $2 \theta$ equal to $32^{\circ}$ and Fig. (11) shows the X-ray diffractogram of poly ferric aluminum chloride silicate (PFeACSi), which indicates the amorphous silica board peak appeared around $2 \theta$ equal to $22^{\circ}{ }^{[38]}$, and the peak in the range of $2 \theta$ equal to $32^{\circ}$.

\subsection{The second part :}

The data listed in table (4) represents the variation of physicochemical properties of ground water with four samples of poly inorganic coagulant silica based, it was shown that : the maximum removal of iron, manganese colour, and turbidity, reach to $97 \%, 25 \%, 73 \%, 74 \%$, in case of PACSi, PACSi PAHSi, and PAIFeCl, respectively, The data listed in table (5) represents the variation of physicochemical properties of alkaline ground water by inorganic polymers; it shown that, the maximum removal of iron, manganese, fluoride, reach to $99 \%, 97 \%, 99 \%$, in case of PFeAICISi, The data listed in table (6) represents the variation of physicochemical properties of alkaline ground water sample spiked with some pollutants; the maximum removal of color, turbidity , Iron , manganese, arsenic, lead, nitrate and fluoride, reach to $67 \%, 86 \%, 99 \%, 57 \%, 97 \%, 98 \%, 79 \%$ and $19 \%$ respectively, in case of $\mathrm{PFeAICISi}$. In all cases the residual aluminium not more than permissible limits $0.2 \mathrm{mg} / \mathrm{l}$, bicarbonate decrease by addition of coagulant due to consumption of alkali by slightly acidic poly inorganic coagulant, concentration of sulphate and chloride increase by using poly inorganic coagulant, concentration of sodium increase due to using sodium carbonate to raise $\mathrm{pH}$, concentration of total dissolved solids and electrical conductivity increased due to spiking of new materials in solution, no considerable variation of calcium, magnesium, potassium, nitrite, phosphate and silicate. In table 7 the treatment of sewage waste water by poly inorganic polymers based on silica showed that, the maximum removal of $\mathrm{BOD}_{5}$, COD and TSS reach to $92 \%, 90 \%, 93 \%$,respectively, with poly ferric aluminum chloride silicate, total dissolved solids increases due to a new spiked ions, no 
variation of $\mathrm{pH}$ occurred, all values after treatment within permissible limits according to Egyptian low 44/2000 . From table 8 the treatment of industrial waste water by poly inorganic polymers showed that, the maximum removal of Lead reach to $99 \%$,in case of PAHSSi .

\section{3. the proposed mechanisms}

Coagulants destabilize colloids and heavy metals by a combination of four mechanisms; these based on compression of the double layer, counter ion adsorption and charge neutralization, enmeshment in a precipitate, and heterocoagulation.[40, 41]

\section{Compression of the Double Layer (DLVO Theory)}

As the concentration of counter ions in solution increases, the counter ions leads to the neutralization of the net charge in the diffused layer and resulted in the compression of this layer. This compression affects the thickness of the entire double layer and so allows colloids to come closer together.

2. Counter ions adsorption and charge neutralization

Counter ions of coagulants can also be adsorbed onto the surface of the colloidal particles. In this way, the repulsive charges on the surface of the particles may be fully neutralized by the charges carried by the counter ions.

3. Enmeshment in a precipitate

The dosage of metal salts used in coagulation is usually slightly in excess of the amount required for reduction of the zeta potential. The excess metal salts hydrolyze into the form $\mathrm{M}(\mathrm{OH})_{6}{ }^{3+}$. These hydroxides are extremely insoluble in water. As the hydroxide precipitate forms and accumulates; the small colloidal particles are entrapped or enmeshed in the hydroxide floc structure ( "enmeshment in a precipitate"; "sweep-floc coagulation").

4. Heterocoagulation

The surface charge on the surface of some naturally occurring particles may not be uniform. Oppositely charged sites may exist on the surface of the same particle. The coagulation of these colloidal particles can therefore occur via simple electrostatic interaction between these oppositely charged sites ("heterocoagulation").

Most particles in water, mineral and organic, have electrically charged surfaces, and the sign of the charge is usually negative [41], in activated silica case, two important processes for producing this charge are considered in the following discussion:

First, surface groups on the solid may react with water and accept or donate protons. For an oxide surface such as silica, the surface site might be indicated by the symbol $\mathrm{SiOH}$ and the surface site ionization reactions take place:

$\mathrm{SiOH}_{2}^{+} \longrightarrow \mathrm{SiOH}+\mathrm{H}^{+}$

$\mathrm{SiOH} \longrightarrow \mathrm{SiO}^{-}+\mathrm{H}+$

Second, surface groups can react in water with solutes other than protons. Again, using the $\mathrm{SiOH}$ surface groups of silica,

$\mathrm{SiOH}+\mathrm{M}^{2+} \longrightarrow \mathrm{SiO} \mathrm{M}+\mathrm{H}^{+}$where, $\mathrm{M}=\mathrm{Fe}, \mathrm{Mn}, \mathrm{As}$, and $\mathrm{Pb}$

$\mathrm{SiOH}+\mathrm{Mo}^{2-} \longrightarrow \mathrm{SiOPO} \mathrm{H}^{-}+\mathrm{OH}^{-}$where, $\mathrm{MO}^{2-}=2 \mathrm{~F}^{-1}, 2 \mathrm{NO}^{-1}$, and $\mathrm{HPO}_{4}{ }^{2}-$ These surface complex formation reactions involve specific chemical reactions 
between chemical groups on the solid surface (e.g., silanol groups) and absorbable solutes (e.g., Lead and Nitrate ions). Surface charge is again related to solution chemistry [41].

\section{CONCLUSIONS}

Within limits of the present study the following conclusion can be derived :

1) Sodium silicate ( activated silica ) was regarded as one of coagulant modifiers which has many features like very fast hydrolysis, promote rapid settling rates, extremely efficient in cold water, give low soluble residual aluminum, consume less alkalinity, very little effect on $\mathrm{pH}$, increase the stability of coagulant and leads to a denser compacted sludge.

2) Poly inorganic coagulant based on silica of iron are more favorable than aluminium due to a broad range and highly density of iron hydroxide than aluminum hydroxide.

3) Mixtures of aluminum and iron poly co-agulants are more efficient in removal of pollutants of waste waters.

4) Maximum removal of ground water pollutants : turbidity, colour, $\mathrm{Fe}, \mathrm{Mn}, \mathrm{Pb}, \mathrm{As}$, $\mathrm{NO}_{3}{ }^{-1}$ and $\mathrm{F}^{-1}$ are found to be about $70 \%, 75 \% 97.5 \%, 96 \%, 97 \%, 97 \%, 97 \%$, and $99 \%$, respectively ,

5) The maximum removal of $\mathrm{Pb}$ in industrial waste water reach to $99 \%$,

6) The maximum removal of BOD, COD and TSS in sewage waste water are found to be $92 \%,, 90 \%$, and $93 \%$, respectively.

7) The maximum doses in all cases about $10 \mathrm{ppm}$ of $\mathrm{Fe}$ and $\mathrm{Al}$ coagulant based on activated silica .

8) The residual aluminium level does not exceed the permissible limits $0.2 \mathrm{mg} / \mathrm{l}$. 
Table( 1): Chemical composition of poly inorganic co-agulants with silica

\begin{tabular}{|r|c|c|c|c|}
\hline Parameter & PACSi & PFeCISi & PAHSSi & PAIFeCISi \\
\hline Al g/l & 3.5 & - & 3.5 & 1.75 \\
\hline F g/l & - & 10 & - & 5 \\
\hline $\mathrm{Si} \mathrm{g/l}$ & 0.35 & 1 & 0.35 & 1 \\
\hline$\beta$ & $66 \%$ & $66 \%$ & $50 \%$ & $66 \%$ \\
\hline $\mathrm{Y}$ & 2.0 & 2.0 & 1.5 & 2.0 \\
\hline
\end{tabular}


Fig( 2 ) : Band components analysis of the infrared spectra $\left(\mathrm{cm}^{-1}\right)$ of poly inorganic coagulants based on silica

\begin{tabular}{|c|c|c|c|c|c|}
\hline $\begin{array}{l}\mathrm{Al}_{13}-\mathrm{O}- \\
\mathrm{Si}(\mathrm{OH})_{3}{ }^{[36]}\end{array}$ & PACSi & PFeCISi & PAIHSSi & PAIFeCISi & Assignment \\
\hline 3740 & 3735 & 3876 & & & Si-OH OH-stretch \\
\hline 3449-3465 & 34345 & 3383 & 3372 & & $\mathrm{OH}$-stretch (1) \\
\hline $3163-3245$ & & & & 3413 & $\mathrm{H}_{2} \mathrm{O} \mathrm{OH}$-stretch (2) \\
\hline $1680-1618$ & 1636 & 1619 & 1671 & 1629 & $\begin{array}{c}\mathrm{H}_{2} \mathrm{O} \text { bend (1), } \mathrm{H}_{2} \mathrm{O} \text { bend } \\
(2)\end{array}$ \\
\hline $\begin{array}{l}1164 \\
1076\end{array}$ & 1086 & 1082 & 1135 & 1121 & $\begin{array}{c}\mathrm{Al}-\mathrm{OH}_{2} / \mathrm{Fe}-\mathrm{OH}_{2} \text { bend (1), } \\
\mathrm{v}_{3} \mathrm{SO}_{4} \\
\text { or } \\
\mathrm{v}_{1} \mathrm{SO}_{4} / \mathrm{Al}-\mathrm{OH}_{2} / \mathrm{Fe}-\mathrm{O} \\
\text { bend (2) }\end{array}$ \\
\hline 984 & 983 & 958 & & 898 & $\begin{array}{c}\mathrm{Al}-\mathrm{OH}_{2} / \mathrm{Fe}-\mathrm{OH}_{2} \\
\text { bend (4) }\end{array}$ \\
\hline $683-706$ & 600 & 689 & & 703 & $\begin{array}{c}\text { Al-O / Fe-O } \\
\text { antisymmetric stretch or } \\
\text { Al-O / Fe-O symmetric } \\
\text { stretch } \\
\text { AL-O-Si / Fe-O-Si }\end{array}$ \\
\hline $593-606$ & & & 606 & & $\mathrm{v}_{4} \mathrm{SO}_{4}$ \\
\hline
\end{tabular}

Fig( 3 ) :Band components analysis of the near infrared spectra $\left(\mathrm{cm}^{-1}\right)$ of poly inorganic coagulants based on silica

\begin{tabular}{|c|c|c|c|c|c|}
\hline $\begin{array}{c}\mathrm{PAC} \\
\mathrm{Al}_{13} \mathrm{SO}_{4}\end{array}$ & PACSi & PAHSSi & PFeCISi & PAIFeCISi & Assignment \\
\hline & 7326 & 7336 & 7378 & 7368,7326 & Overtone $\mathrm{OH}$-stretch $\mathrm{Si}-\mathrm{OH}$ \\
\hline 7018 & $\begin{array}{c}7040 \\
6984 \\
\end{array}$ & $\begin{array}{c}7020 \\
6982-6914\end{array}$ & 6898 & 7040 & $\begin{array}{c}\text { Overtone } \mathrm{OH} \text {-stretch (1) } \mathrm{AlOH} \\
\text { or FeOH }\end{array}$ \\
\hline 6777 & $\begin{array}{l}6787- \\
6823\end{array}$ & 6871 & 6813 & $\begin{array}{c}6802- \\
6743\end{array}$ & $\begin{array}{c}\text { Combination OH-stretch } \\
(1+2) \mathrm{AlOH}+\text { crystal } \mathrm{H}_{2} \mathrm{O} \text { or } \\
\mathrm{FeOH}\end{array}$ \\
\hline 6213 & - & - & 6248 & $6446-6366$ & $\begin{array}{l}\text { Overtone } \mathrm{OH} \text {-stretch (2) } \\
\text { crystal } \mathrm{H}_{2} \mathrm{Oor} \mathrm{FeOH}\end{array}$ \\
\hline 5703 & 5436 & 5436 & 5778 & 5199 & $\begin{array}{c}\text { Overtone } \mathrm{AlOH}(3 / 4) \text { bend or } \\
\mathrm{FeOH}\end{array}$ \\
\hline 5236 & 5341 & 5341 & 5513 & - & $\begin{array}{l}\mathrm{H}_{2} \mathrm{O} \text { combination (bend } 1+ \\
\text { stretch 1) } \mathrm{Al}_{13, \text { or }} \mathrm{FeOH}\end{array}$ \\
\hline 5158 & 5181 & 5177 & 5138 & - & $\begin{array}{l}\mathrm{H}_{2} \mathrm{O} \text { combination (bend } 2+ \\
\text { stretch 1) crystal } \mathrm{H}_{2} \mathrm{O}+\mathrm{Al}_{13} \text {, or } \\
\text { FeOH }\end{array}$ \\
\hline 4553 & 4463 & - & 4565 & - & $\begin{array}{c}\text { Combination } \mathrm{AlOH} \text { (stretch } 1+ \\
\text { bend } 3 \text { or } 4 \text { ) or } \mathrm{FeOH}\end{array}$ \\
\hline
\end{tabular}


Table( 4 ):Variations of physicochemical parameters of ground water samples by influence of poly inorganic co-agulants based on silica

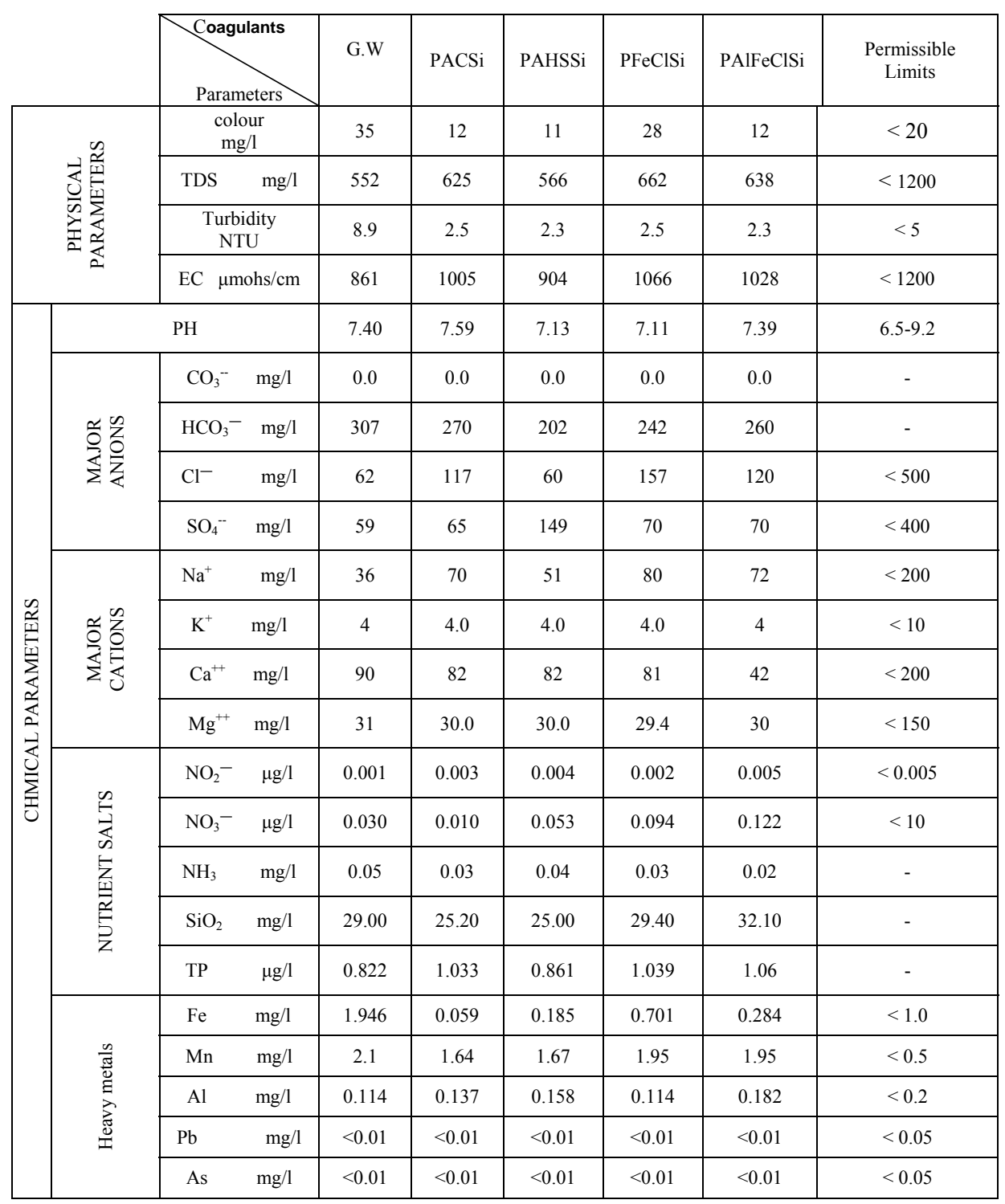


Table (5):Variations of physicochemical parameters of alkaline ground water samples by influence of poly inorganic co-agulants based on silica

\begin{tabular}{|c|c|c|c|c|c|c|c|c|}
\hline & & Coagulant & G.W & PACSi & PAHSSi & $\mathrm{PFeClSi}$ & PAlFeClSi & $\begin{array}{l}\text { Permissible } \\
\text { Limit } 1\end{array}$ \\
\hline & & $\begin{array}{c}\text { colour } \\
\mathrm{mg} / 1\end{array}$ & 13 & 5 & 5 & 6 & 6 & $<20$ \\
\hline & 导窇 & $\begin{array}{l}\text { TDS } \\
\mathrm{mg} / 1\end{array}$ & 507 & 716 & 779 & 797 & 726 & $<1200$ \\
\hline & 式 & $\begin{array}{c}\text { Turbidity } \\
\text { NTU }\end{array}$ & 2.1 & 1.3 & 1.3 & 1.4 & 2.0 & $<5$ \\
\hline & & $\begin{array}{c}\text { EC } \\
\mu \mathrm{mohs} / \mathrm{cm}\end{array}$ & 788 & 1118 & 1206 & 1247 & 1133 & $<1200$ \\
\hline & & PH & 7.37 & 8.26 & 0.08 & 8.19 & 8.26 & $6.5-9.2$ \\
\hline & & $\mathrm{CO}_{3}^{--} \quad \mathrm{mg} / \mathrm{l}$ & 0.0 & 35.0 & 20.0 & 35.0 & 45 & - \\
\hline & 증 & $\mathrm{HCO}_{3}^{-} \mathrm{mg} / 1$ & 305 & 347 & 395 & 350 & 347 & - \\
\hline & 文艺 & $\mathrm{Cl}^{-} \quad \mathrm{mg} / \mathrm{l}$ & 47 & 110 & 48 & 151 & 107 & $<500$ \\
\hline & & $\mathrm{SO}_{4}^{--} \quad \mathrm{mg} / \mathrm{l}$ & 48 & 60 & 151 & 63 & 64 & $<400$ \\
\hline & & $\mathrm{Na}^{+} \quad \mathrm{mg} / \mathrm{l}$ & 33.0 & 176 & 144 & 187 & 185 & $<200$ \\
\hline 焉 & 告 & $\mathrm{K}^{+} \quad \mathrm{mg} / \mathrm{l}$ & 4.0 & 3.0 & 3.0 & 4.0 & 3.0 & $<10$ \\
\hline$\sum$ & $\sum$ & $\mathrm{Ca}^{++} \quad \mathrm{mg} / \mathrm{l}$ & 86.0 & 38 & 78 & 52 & 26.0 & $<200$ \\
\hline 紫 & & $\mathrm{Mg}^{++} \quad \mathrm{mg} / \mathrm{l}$ & 32.6 & 30.0 & 32.6 & 31.2 & 34.8 & $<150$ \\
\hline 亗 & & $\mathrm{NO}_{2}^{-} \quad \mu \mathrm{g} / 1$ & 0.013 & 0.011 & 0.012 & 0.011 & 0.012 & $<0.005$ \\
\hline 売 & $\underset{⿱ 乛 龰}{2}$ & $\mathrm{NO}_{3}^{-} \quad \mu \mathrm{g} / 1$ & 0.782 & 0.713 & 0.613 & 0.666 & 0.670 & $<10$ \\
\hline & 艺 & $\mathrm{NH}_{3} \quad \mathrm{mg} / \mathrm{l}$ & 0.03 & 0.02 & 0.03 & 0.02 & 0.02 & - \\
\hline & $\overline{\underline{\varepsilon}}$ & $\mathrm{SiO}_{2} \quad \mathrm{mg} / \mathrm{l}$ & 28.40 & 20.70 & 16.20 & 24.60 & 20.10 & - \\
\hline & $\bar{z}$ & ТP $\quad \mu \mathrm{g} / 1$ & 0.410 & 0.095 & 0.077 & 0.069 & 0.109 & - \\
\hline & & $\mathrm{Fe} \quad \mathrm{mg} / \mathrm{l}$ & 2.5 & 0.1 & 0.05 & 0.09 & 0.008 & $<1.0$ \\
\hline & 苋 & $\mathrm{mg} / \mathrm{l}$ & 1.5 & 0.083 & 0.608 & 0.163 & 0.044 & $<0.5$ \\
\hline & 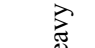 & $\mathrm{Al} \quad \mathrm{mg} / \mathrm{l}$ & 0.1 & 0.116 & 0.130 & 0.025 & 0.142 & $<0.2$ \\
\hline & $I$ & $\mathrm{~F} \quad \mathrm{mg} / \mathrm{l}$ & 1.0 & 0.87 & 0.93 & 0.13 & 0.01 & $<0.8$ \\
\hline
\end{tabular}


Table ( 6 ) : Variations of physicochemical parameters of alkaline ground water samples polluted with arsenic lead, nitrate and fluoride by influence of poly inorganic co-agulants based on silica .

\begin{tabular}{|c|c|c|c|c|c|c|c|c|}
\hline & & $\overbrace{\text { Parameters }}^{\text {coagulant }}$ & G.W & PACSi & PAHSSi & $\mathrm{PFeClSi}$ & $\begin{array}{c}\text { PAlFeCl } \\
\mathrm{Si}\end{array}$ & $\begin{array}{l}\text { Permissible } \\
\text { limits }\end{array}$ \\
\hline & & $\begin{array}{c}\text { colour } \\
\mathrm{mg} / \mathrm{l}\end{array}$ & 13 & 8 & 7 & 5 & 6 & $<20$ \\
\hline & 安舀 & $\begin{array}{l}\mathrm{TDS} \\
\mathrm{mg} / \mathrm{l}\end{array}$ & 559 & 780 & 705 & 822 & 682 & $<1200$ \\
\hline & 式 & $\begin{array}{c}\text { Turbidity } \\
\text { NTU }\end{array}$ & 8.7 & 1.9 & 1.8 & 1.2 & 1.4 & $<5$ \\
\hline & & $\begin{array}{c}\text { EC } \\
\mu \mathrm{mohs} / \mathrm{cm}\end{array}$ & 887 & 1204 & 1130 & 1278 & 1089 & $<1200$ \\
\hline & & PH & 7.45 & 8.33 & 7.58 & 7.67 & 8.07 & $6.5-9.2$ \\
\hline & & $\mathrm{CO}_{3}^{--} \quad \mathrm{mg} / \mathrm{l}$ & 0.0 & 45 & 0.0 & 25 & 10.0 & - \\
\hline & 응 & $\mathrm{HCO}_{3}^{-} \mathrm{mg} / \mathrm{l}$ & 250 & 302 & 295 & 302 & 272 & - \\
\hline & 㐫茹 & $\mathrm{Cl}^{-} \quad \mathrm{mg} / \mathrm{l}$ & 65 & 118 & 67 & 145 & 115 & $<500$ \\
\hline & & $\mathrm{SO}_{4}^{--} \quad \mathrm{mg} / 1$ & 84 & 124 & 168 & 120 & 92 & $<400$ \\
\hline & & $\mathrm{Na}^{+} \quad \mathrm{mg} / \mathrm{l}$ & 48 & 128 & 113 & 148 & 135 & $<200$ \\
\hline 舀 & 㔯资 & $\mathrm{K}^{+} \quad \mathrm{mg} / \mathrm{l}$ & 4.0 & 3.0 & 3.0 & 3.0 & 3 & $<10$ \\
\hline$\sum$ & 完它 & $\mathrm{Ca}^{++} \mathrm{mg} / \mathrm{l}$ & 86 & 80 & 80 & 80 & 54 & $<200$ \\
\hline 永 & & $\mathrm{Mg}^{++} \quad \mathrm{mg} / 1$ & 28.1 & 28.8 & 28.8 & 30.0 & 27.6 & $<150$ \\
\hline 岂 & is & $\mathrm{NO}_{2}^{-} \quad \mu \mathrm{g} / 1$ & 0.389 & 0.039 & 0.026 & 0.020 & 0.039 & $<0.005$ \\
\hline 夏 & 宗 & $\mathrm{NO}_{3}{ }^{-} \quad \mu \mathrm{g} / 1$ & 7.731 & 1.947 & 2.313 & 2.911 & 1.634 & $<10$ \\
\hline & 它 & $\mathrm{NH}_{3} \quad \mathrm{mg} / \mathrm{l}$ & 0.81 & 0.57 & 0.80 & 0.69 & 0.87 & - \\
\hline & 葛 & $\mathrm{SiO}_{2} \quad \mathrm{mg} / \mathrm{l}$ & 28.20 & 22.80 & 22.80 & 26.80 & 23.00 & - \\
\hline & z & ТР $\quad \mu \mathrm{g} / 1$ & 2.517 & 1.694 & 1.379 & 1.158 & 1.645 & - \\
\hline & & $\mathrm{Fe} \quad \mathrm{mg} / 1$ & 2.1 & 0.063 & 0.044 & 0.049 & 0.097 & $<1.0$ \\
\hline & $\frac{n}{5}$ & $\mathrm{Mn} \quad \mathrm{mg} / \mathrm{l}$ & 1.243 & 0.890 & 1.190 & 1.245 & 0.532 & $<0.5$ \\
\hline & $\begin{array}{l}7 \\
3\end{array}$ & $\mathrm{Al} \quad \mathrm{mg} / \mathrm{l}$ & 0.113 & 0.207 & 0.256 & 0.057 & 0.076 & $<0.2$ \\
\hline & 扂 & $\mathrm{Pb} \quad \mathrm{mg} / 1$ & 13.559 & 1.613 & 1.860 & 0.319 & 1.533 & $<0.0 .5$ \\
\hline & & As & 1.221 & 0.257 & 0.128 & 0.096 & 0.032 & 0.05 \\
\hline & & $\mathrm{mg} / 1$ & 2.889 & 3.429 & 2.966 & 3.017 & 2.892 & 0.8 \\
\hline
\end{tabular}


Table ( 7 ):Effect of poly inorganic polymers based on silica of sewage waste water

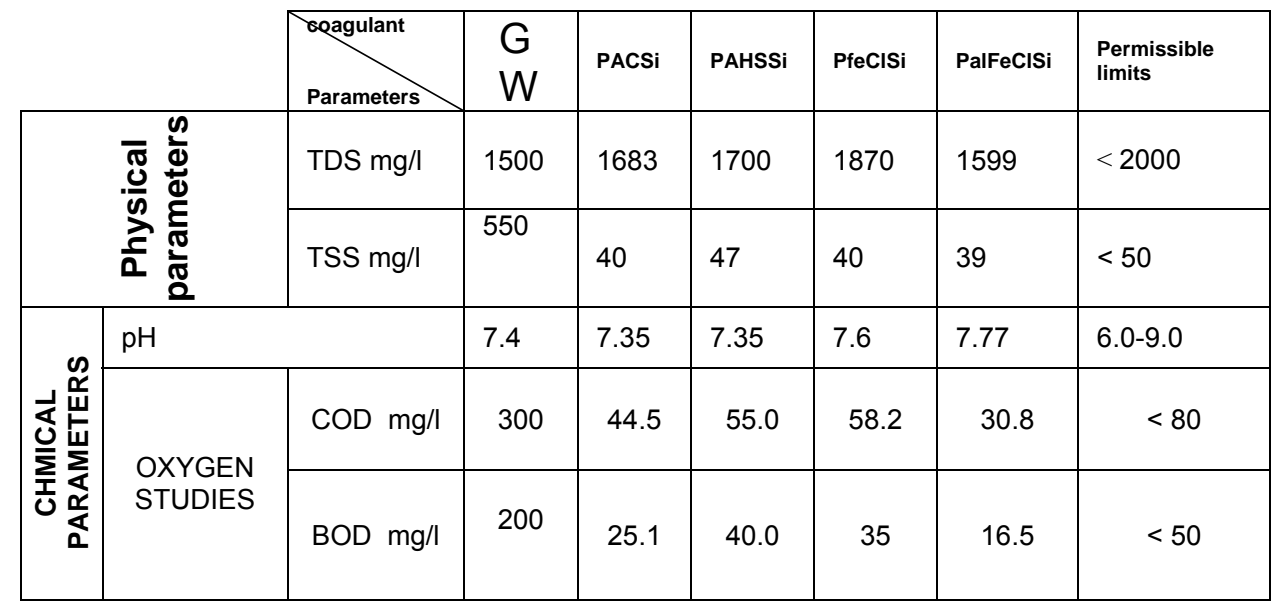

Table ( 8 ) :Effect of poly inorganic polymers based on silica of on industrial waste water

\begin{tabular}{|c|c|c|c|c|c|c|}
\hline$\overbrace{\text { Parameters }}^{\text {Stations }}$ & Spiked & PACSi & PAIFeCl & PAHSSi & PAIFeCISi & $\begin{array}{l}\text { Permissible } \\
\text { limits }\end{array}$ \\
\hline $\mathrm{H}$ & 3.5 & 8.97 & 8.68 & 7.05 & 8.65 & $6.0-9.0$ \\
\hline $\mathrm{Pb} \mathrm{mg} / \mathrm{l}$ & 50.0 & 0.078 & 1.438 & 0.01 & 1.411 & $<0.05$ \\
\hline
\end{tabular}




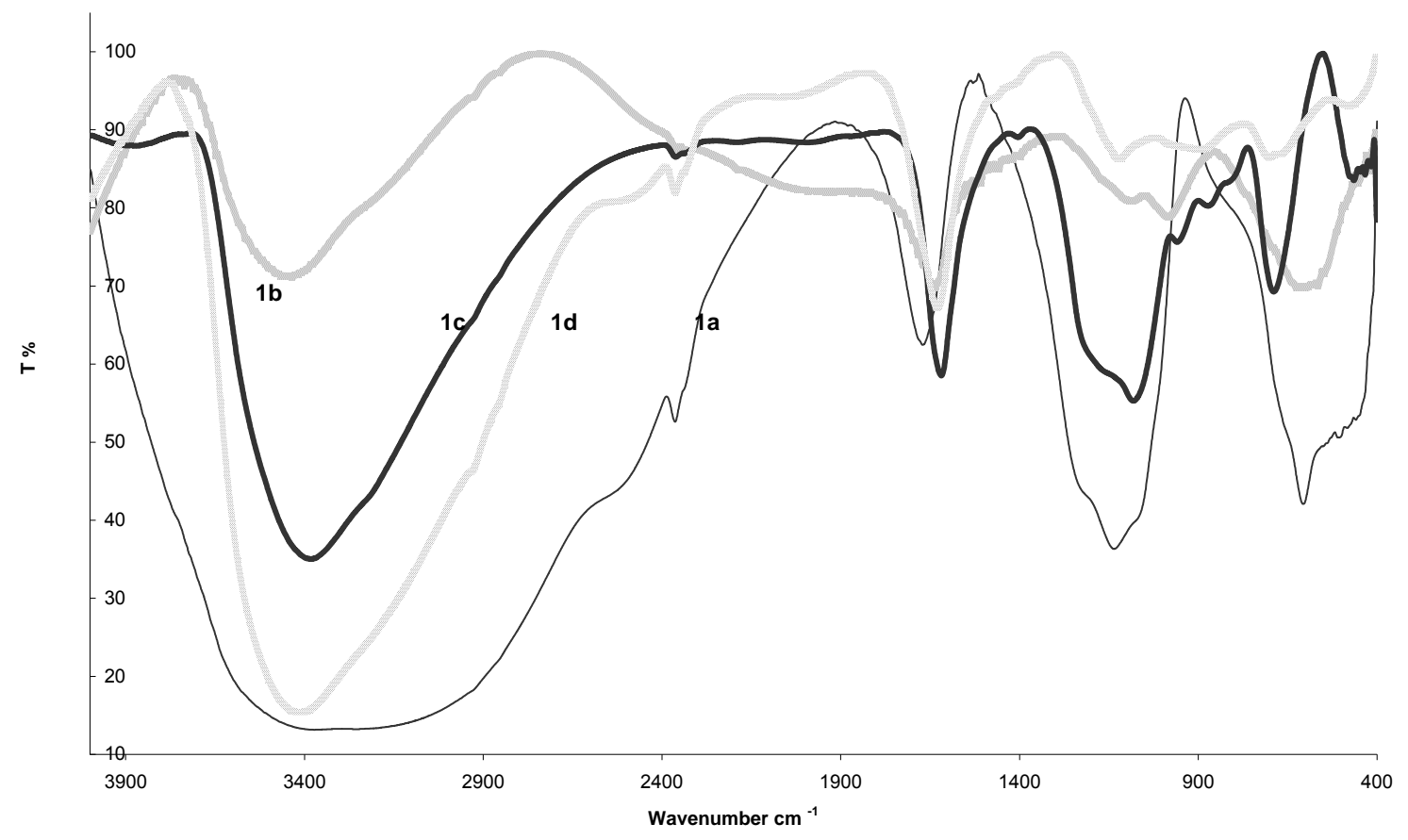

Fig. 1: FTIR spectra of a-.PAIHSSi, b- PACISi, c -PFeCISi, d-PAIFeCISi

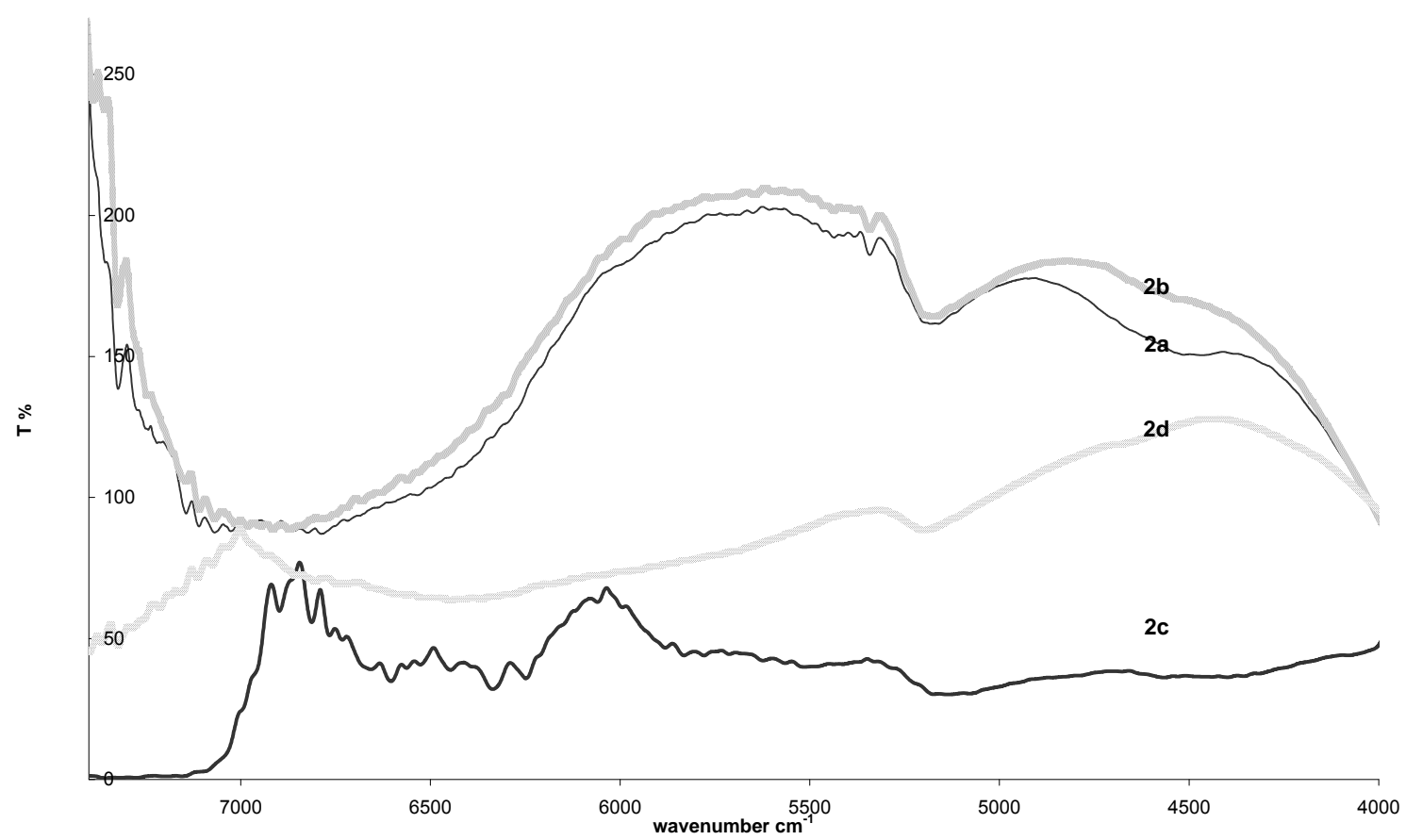

Fig. 2 : NFTIR spectra of a-.PACSi, b- -.PAHSSi, c -PFeCISi, d-PFeAICISi 


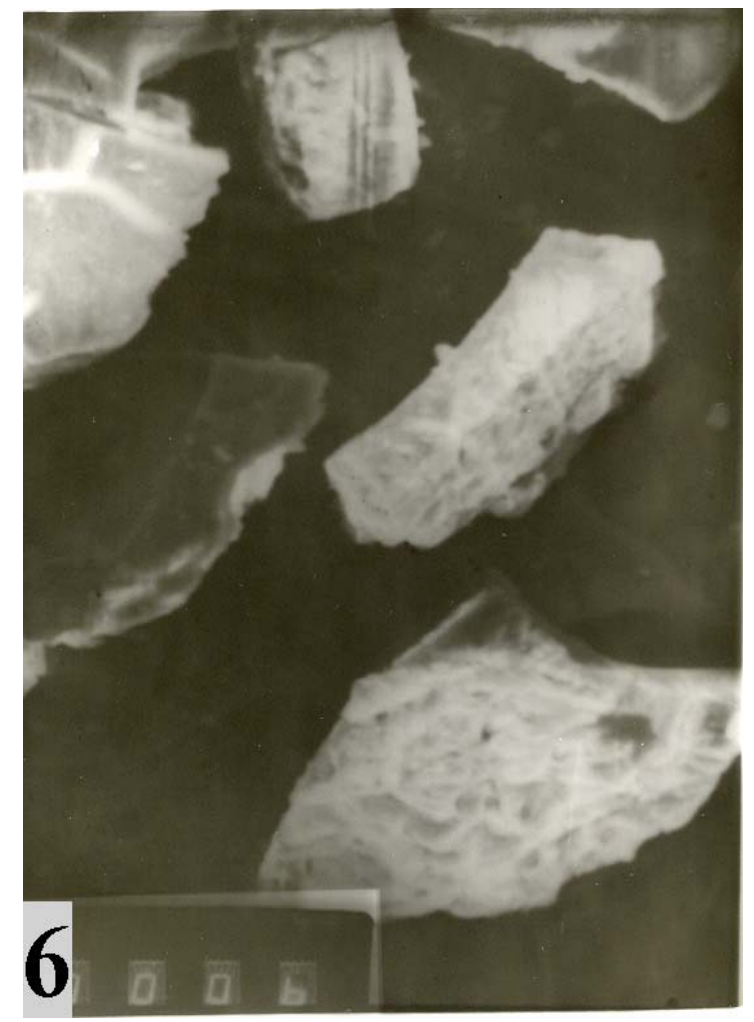

Fig. 3 : SEM micrograph of $\mathrm{PACSi}-\mathrm{C}_{2} \mathrm{O}_{4} \times 100$

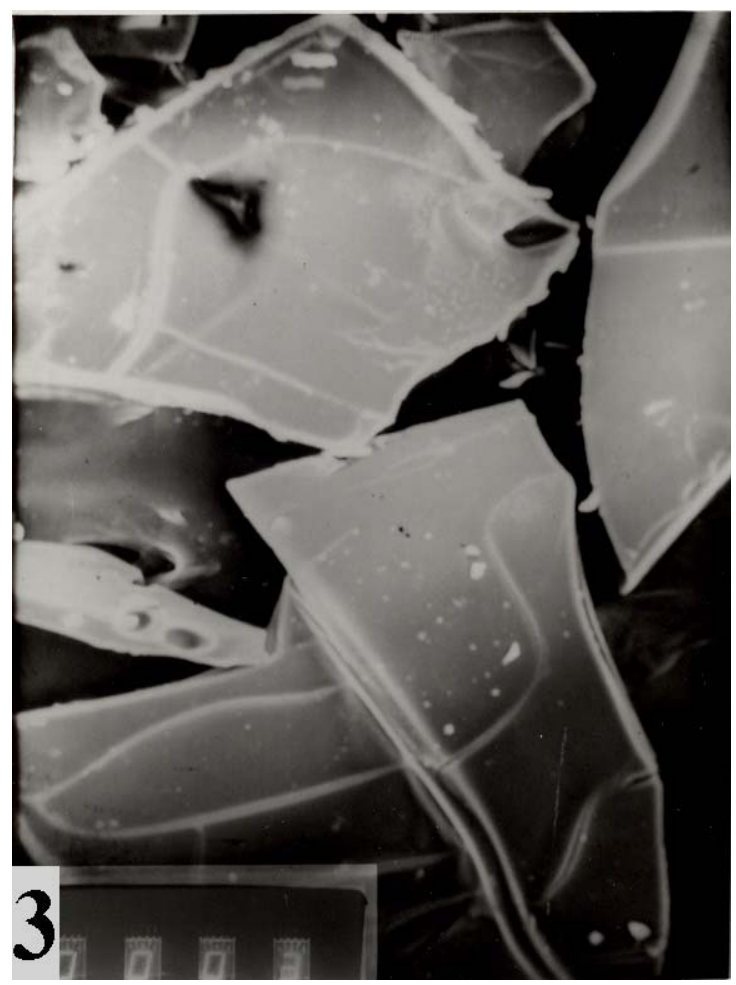

Fig. 5: SEM micrograph of PAHSSi X100

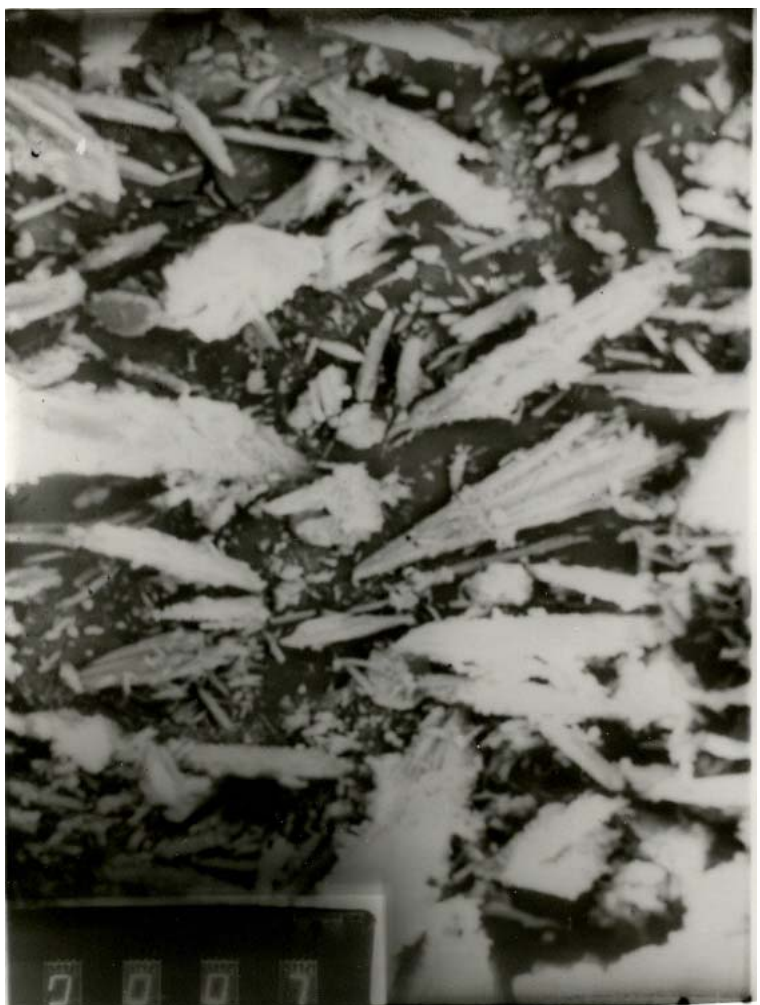

Fig. 4: SEM micrograph of PACSi-SO ${ }_{4} \mathrm{X} 100$

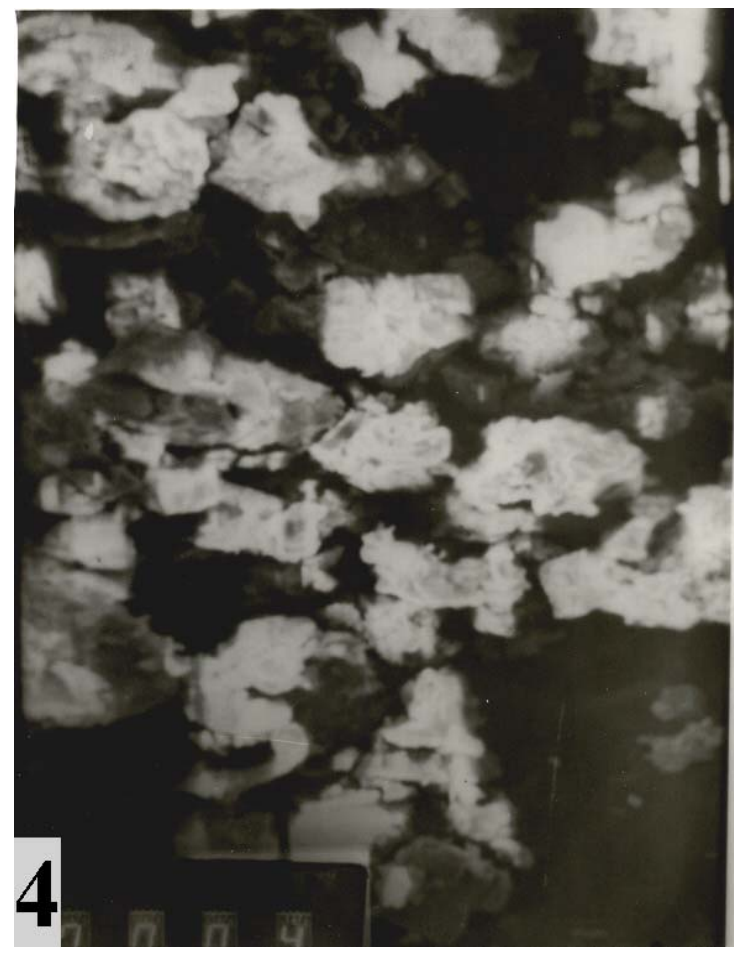

Fig.6 :SEM micrograph of PFeCISi X100 


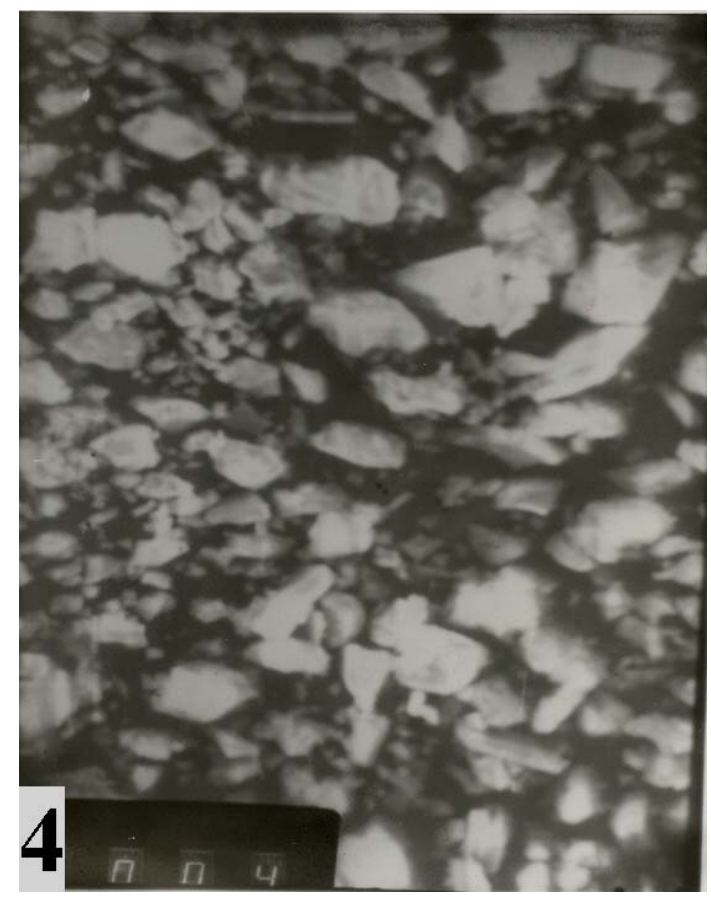

Fig. 7: SEM micrograph of PFeAICISi X100

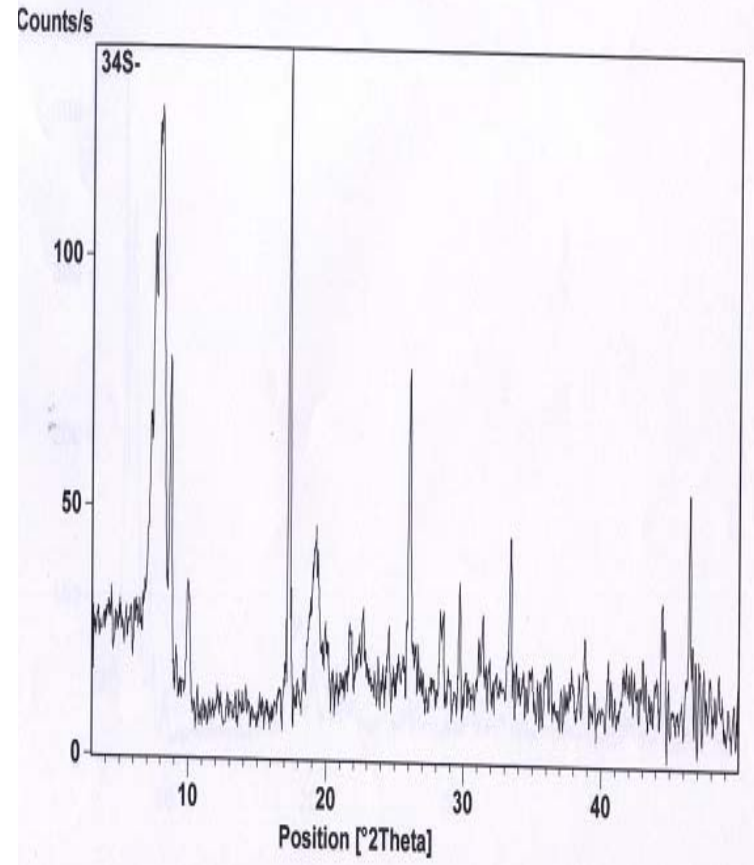

Fig. 8 : XRD diffractogram of PACSi

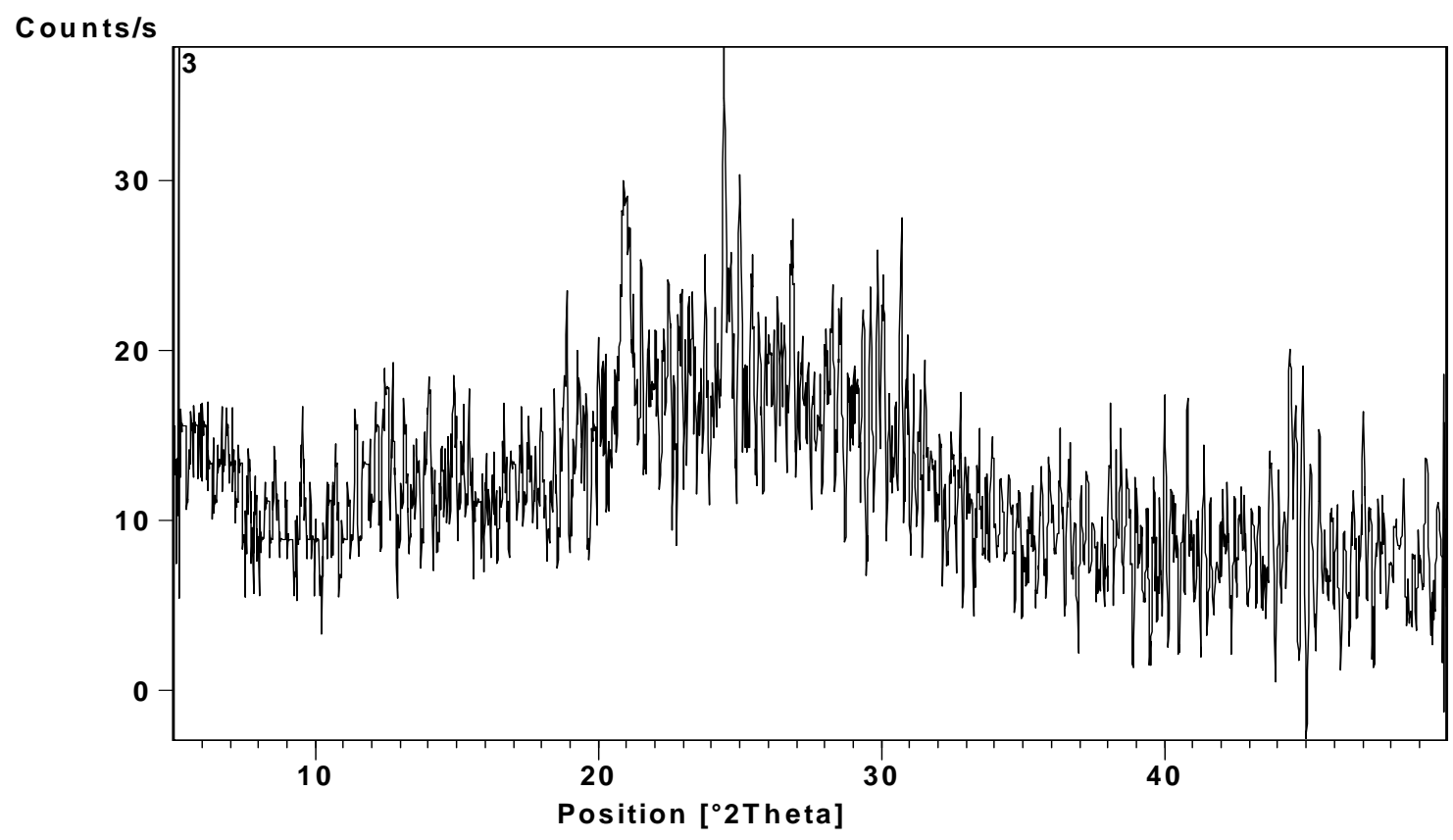

Fig. 9: XRD diffractogram of PAHSSi 


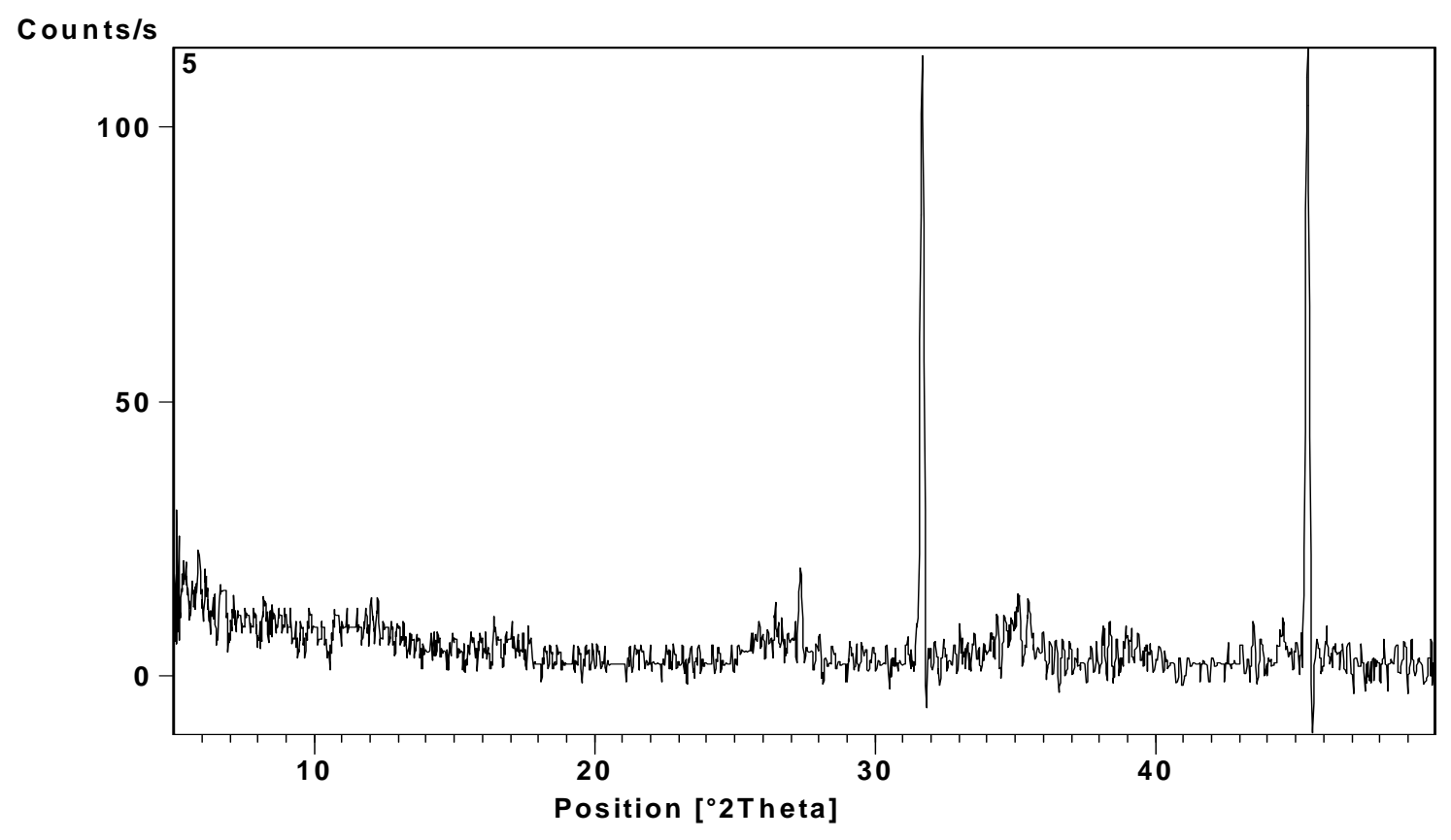

Fig. 10 : XRD diffractogram of $\mathrm{PFeCISi}$

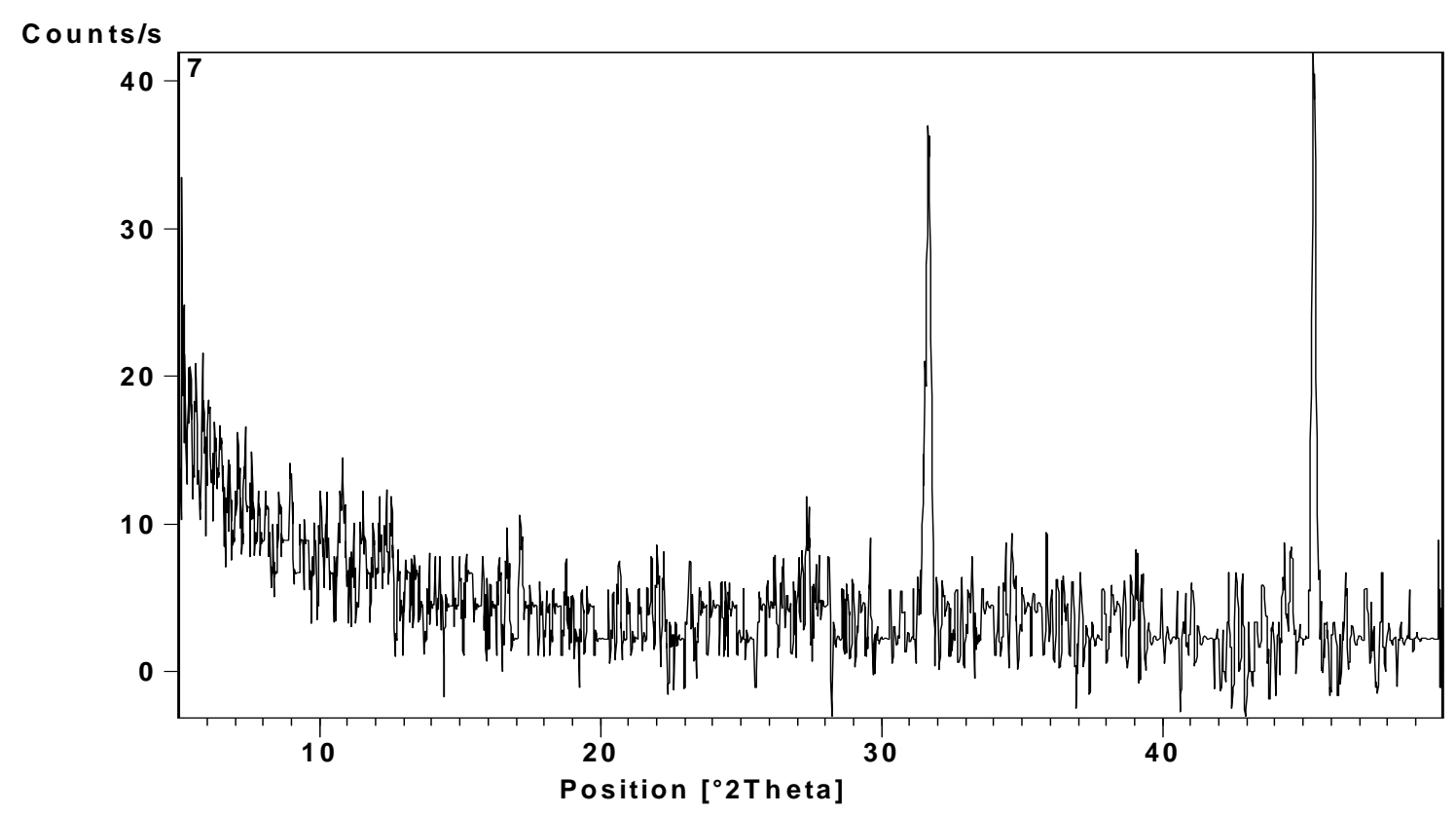

Fig $11:$ XRD diffractogram of PFeAICISi 


\section{REFERENCES:}

[1] J. Gregory, and J. Duan, Hydrolyzing metal salts as coagulants Pure Appl. Chem., 73,. 2017-2026 (2001).

[2] D. T. Richens. The Chemistry of Aqua Ions, ch.2, Wiley, Chichester (1997).

[3] H.X. Tang, Basic studies of inorganic polymer flocculants, Environ. Chem. 9 1-12 (1990).

[4] D.S.Wang, H.X.Tang, J.Gregory, Relative importance of charge neutralization and precipitation during coagulation with IPF-PACI . Environ. Sci., Technol., 36 (8), 3866 (2002).

[5] I.M. Solomentseva, N.G. Gerasimenko, S. Barany, Colloids Surf., 151,113126 (1999)

[6] Y. Matsui, A. Yuasa, Y. Furuya, T. Kamei, J. Am. Water Wks Assn.88 (10) 96-106(1996).

[7] H.X. Tang, B.Z. Tian, Z.K. Luan, Y. Zhang, PFCl, in: R. Klute, H.H. Hahn (Eds.), Chemical Water and Wastewater Treatment (III),Springer-Verlag, 5769 (1994).

[8] H.X. Tang, Z.K. Luan, D.S. Wang, B.Y. Gao, Compsite inorganic polymer flocculant, in H.H. Hahn, et al. (Eds.), Chemical Water and Wastewater Treatment (V), Springer-Verlag ,24-33(1998).

[9] D.S. Wang, H.X. Tang, Modified inorganic polymer flocculant-PFSi:its preparation, characterization and coagulation behavior, Water Res.,35 (14) 3418-3428(2001).

[10] K. A Gray, C.H. Yao, C.R. O'Melia. J. Am. Water Wks Assn. 87 (4) 136(1995).

[11] H.X. Tang, Z.K. Luan, the different behavior and mechanism between inorganic polymer flocculant and traditional coagulants, in: H.H.Hahn, et al. (Eds.), Chemical Water and Wastewater Treatment (IV),Springer-Verlag, 83-93(1996).

[12] J. Van Benschoten, J.K. Edzwald, Water Res. 24, 1519(1990).

[13] P.M. Bertsch, D.R. Parker, Aqueous polynuclear aluminum species, in: G. Sposito (Ed.), The Environmental Chemistry of Aluminum,CRC Press, 87115(1996).

[14] M.A. Blesa, E. Matijevic, Phase transformations of iron oxides, oxohydroxides, and hydrous oxides in aqueous media, Adv. Colloid Interface Sci. 29, 173-221(1989).

[15] R.M. Cornell, R. Giovdnoli, W. Schneider, Review of the hydrolysis of iron(III) and the crystallization of amorphous iron(III) hydroxide hydydrate, J. Chem. Tech. Biotechl. 46, 115-134(1989).

[16] P.M. Jardine, L.W. Zelazny, Mononuclear and polynuclear aluminum speciation through differential kinetic reactions with ferron, Soil Sci.Soc. Am. J. 50 895(1986).

[17] P.H. Hsu, D. Cao, Effects of acidity and hydroxylamine on the determination of aluminum with ferron, Soil Sci. 152 (3) 210-219(1990).

[18] D.R. Parker, P.M. Bertsch, Identification and quantification of the Al13 tridecameric polycation using ferron, Environ. Sci., Technol., 26, 908(1992).

[19] J. E Van Benchosten. and J. K Edzwald. Chemicala spects using aluminum salts. I. Hydrolytic reactions of alum and polyaluminum chloride. Wat. Res. 24,1519-1526(1990). 
[20] A. K Arnold-Smith., R. M. Christie and C. Jolicoeur Polyaluminium silicate sulphate: a new coagulant for potable and waste water treatment. In Proceedings of the ${ }^{5}$ International Gothenberg Symposium on Chemical Treatment, Springer-Verlag, New York, 203-222(1992).

[21] B.Y. Gaoa, H.H. Hahnb, E. Hoffmannb,* Evaluation of aluminum-silicate polymer composite as a coagulant for water treatment Water Research 36 3573-3581(2002).

[22] T. Hasegawa, K. Hashimoto, T. Onitsuka, K. Goto, N. Tambo,Wat. Sci. Tech., 23 1713(1991).

[23] K. Hashimoto, T. Hasegawa,O.T. Goto, N. Tambo, Water Supply 9, 65(1991).

[24] B.Y. Gao, Q.Y. Yue, S.R. Wang, Chin. J. Environ., Sci., 11, 37 (1990).

[25] Y. Matsui, A.Yuasa,Y. Furuya, T. Kamei, Dynamic analysis of coagulation with alum and PACl, J. Am. Water Works Ass., 90, 96-106(1998).

[26] I.M. Solomentseva, N.G. Gerasimenko, S. Barany, Surface properties and aggregation of basic aluminium chloride hydrolysis products, Colloid Surf.A: Physicochem. Eng., Asp., 151, 113-126(1999).

[27] S.K. Dentel, Coagulation control in water treatment, CRC Crit. Rev. Environ.Control, 21, 41-135(1991).

[28] T. Tseng, B.D. Segal, M. Edwards, Increasing alkalinity to reduce turbidity,J. Am. Water Works Ass., ,92, 4-54(2000).

[29] M. Swiderska-Broz,M. Rak, On the importance of aluminum coagulant basicity in organic matter removal, in: H.H. Hahn, E. Hoffmann, H.Odegaard (Eds.), Chemical Water and Wastewater Treatment VII, IWA Publishing, London, 153-161(2002).

[30] J. Duan, J. Gregory, Coagulation by hydrolysing metal salts, Adv., Colloidl nterface Sci., 100-102, 475-502(2003).

[31] Z.K. Chowdhury, G.L. Amy, Coagulation of submicron colloids in water treatment by incorporation into aluminum hydroxide floc, Environ. Sci., Technol., 25, 1766-1773(1991)

[32] H.X. Tang, Z.K. Luan, et al., The differences of behavior and mechanism between pre-polymeric inorganic flocculants and traditional coagulants, in:H.H Hahn Ed. Chemical Water and Wastewater Treatment (IV), Springer Verlag, New York, 57-65 (1996).

[33] K.A. Gray, C.H.Yao, C.R. O'Melia, Inorganic metal polymers: preparation and characterization, J. Am. Water Works Ass., 87, 136-146(1995).

[34] D.S. Wang, H.X. Tang, J. Gregory, Relative importance of charge neutralization and precipitation on coagulation of kaolin with PACl: Effect of sulfate ion, Environ., Sci., Technol., 36, 1815-1820(2002).

[35] J.T. Kloprogge, R.L. Frost, Raman and infrared spectroscopic investigation of the neutralization of aluminium in the presence of monomeric orthosilicic acid Spectrochim. Acta A 55 1359-1369(1999).

[36] J. Theo Kloprogge *, Hu. Ruan, L. Ray Spectrochimica Acta., Part A 56, 2405-2411(2000).

[37] J.T. Kloprogge, R.L. Frost, J. Mater Raman and infrared microscopy study of zunyite, a natural $\mathrm{Al}_{13}$ silicate. Sci., 5, 1505-1513(1999).

[38] Y., Xu , and etal Optimization of the separation and purification of Al13, Colloids and Surfaces Physicochem. Eng., Aspects, 231,1-9 (2003) 
[39] B.j.,wang, S.G.wang Wang, Shu-Guang Wang Characterization and coagulation of a polyaluminum chloride (PAC)coagulant with high $\mathrm{Al}_{13}$ content Journal of Environmental Management $76,143-147$ (2005).

[40] M. Muhammad and M. Wang ; NOVEL SYNTHESIS OF $\mathrm{Al}_{13}$-CLUSTER BASED ALUMINA MATERIALS Nano structured material ,11, 1219-1229 (1999).

[41] R.A., Niehof, and G. I. Loeb. "The surface charge of particulate matter in sea water." Limnology Oceanography, 17, 7(1992). 